\title{
PENERAPAN AKUNTANSI, AKUNTABILITAS DAN PENGENDALIAN INTERNAL PADA GEREJA KRISTEN JAWA WEDI
}

\author{
Wahyu Jati Agung Prabowo ${ }^{1)}$ \\ Lulus Kurniasih $^{2)}$
}

Universitas Sebelas Maret Surakarta ${ }^{1,2)}$

\begin{abstract}
Abstrac : This study discusses the application of accounting, accountability and internal control contained in the Gereja Kristen JawaWedi Klaten, because a lot of corruption in religious institutions. The purpose of this study was to analyze and evaluate the implementation of accounting, accountability and internal controls exist in Gereja Kristen JawaWediKlaten. The method used in this research is qualitative descriptive method, that is by direct observation, interviews, and literature. This research was conducted in Gereja Kristen JawaWediKlaten which is a non-profit religious organization. Research results obtained Gereja Kristen JawaWediKlaten namely the application of accounting, accountability, and internal controls are already well underway, but there are some shortcomings that reporting is not in accordance with IAS 45, the employee who is not competent, and yet there is a good division of labor
\end{abstract}

Keywords : Nonprovit organization, church accounting, accountabilty, internal control

\section{PENDAHULUAN}

1.1 Latar Belakang

Korupsi merupakan kejahatan pidana yang mendapat perhatian khusus dari pemerintah di berbagai negara. Menurut Abdullah Hehamahua dalam Ermansjah Djaja, korupsi tergolong dalam kategori extra-ordinary crimes, karena tidak hanya merusak keuangan negara, tetapi juga pilar - pilar sosial budaya, moral, politik dan tatanan hukum dan keamanan nasional.Kejahatan korupsi selalu identik dengan lembaga pemerintahan, namun sekarang telah berkembang hingga lembaga keagamaan yang dianggap "suci" oleh masyarakat. Seperti yang tertulis di dalam tempo.com pada bulan November tahun 2015, masyarakat singapura dikejutkan dengan ditangkapnya tokoh Gereja City Harvest, salah satu gereja terbesar di Singapura dengan jemaat berjumlah 17.500 orang. Hakim pengadilan singapura menetapkan Kong Hee selaku pendiri sekaligus pendeta Gereja City Harvest bersalah, hal itu dikarenakan Kong Hee menggelapkan uang sumbangan dengan nilai 35 juta dolar Singapura atau sekitar Rp 350 miliar untuk mendanai karier bernyanyi istrinya yang bernama Sun Hoo (bbc.com). Di Indonesia sendiri, kasus penyalahgunaan uang di gereja juga pernah terjadi. Pada Tahun 2013, Pdt. Abraham Alex Tanuseputra diduga melakukan pencucian uang dengan nilai 4,7 triliun rupiah dan pemalsuan akta pendirian bangunan gereja (detiknews.com). Adanya kasus korusi dalam lingkungan gereja menimbulkan kecurigaan atara jemaat dengan pengelola keuangan gereja. Hal ini sesuai dengan penelitian Silvia (2011) yang mengatakan adanya kecurigaan jemaat bahwa persembahan yang mereka berikan digunakan oleh pribadi dan tidak dikelola dengan baik oleh majelis selaku pengelola keuangan gereja. Untuk menghindari adanya korupsi di dalam gereja dan meyakinkan jemaat, gereja perlu melakukan perbaikan. Perbaikan diharapakan tidak hanya sebatas bangunan dan sistem kepengurusan seperti saat ini, melainkan perbaikan dalam pengelolaan keuangan yang transparan yang mengarah pada pertanggungjawaban. 
Penelitian mengenai pengelolaan keuangan dan akuntabilitas dalam organisasi keagamaan pernah dilakukan sebelumnya, beberapa diantaranya oleh Silvia dan Anshar (2011) yang membahas membahas mengenai akuntabilitas pada Gereja Protestan Indonesia yang berada di Palu. Di dalam penelitian ini dapat disimpulkan bahwa "ketidakberesan" dalam administrasi gereja terjadi karena jemaat dan majelis sebagai pengelola tidak saling menopang, serta kepercayaan merupakan sesuatu yang diwajibkan karena sesuai dengan ajaran. Penelitian berikutnya oleh Pontoh (2013) meneliti tentang penerapan laporan keuangan organisasi nirlaba berdasarkan PSAK No 45 pada Gereja Bukit Zaitun Luwuk. Penelitian ini menyimpulkan bahwa Gereja Bukit Zaitun Luwuk belum melakukan pelaporan keuangan sesuai dengan format laporan keuangan organisasi nirlaba yang terdapat dalam Pernyataan Standar Akuntansi No. 45. Namun secara umum fotmat laporan keuangan Gereja Bukit Zaitun Luwuk sudah dapat memberikan informasi yang diperlukan bagi pihak internal dan eksternal.Padatahun1999 John B. Duncan melakukan penelitian dengan judul penelitian Internal control systems in US churches (An examination of the effects of church size and denomination on systems of internal control) yang bertujuan mengevaluasi efek dari ukuran gereja serta politik dan struktur denominasi pada sistem pengendalian internal. Pada tahun 2005, penelitian mengenai akuntansi di gereja juga dilakukan oleh Helen Irvine dengan judul Balancing money and mission in a local church budget. Dalam penelititan ini menjelaskan bagaimana penyusunan anggaran dalam gereja dengan mempertimbangkan kemungkinan terjadinya konflik antara ajaran dengan sifat sekuler dalam akuntansi.

Dalam penelitian ini penulis membahas mengenai bagaimana pengeloaan dan akuntabilitas keuangan pada Gereja Kristen di Wedi. Penulis tertarik untuk meneliti mengenai bagaimana pengelolaan dan akuntabilitas keuangan pada gereja dan pengendalian internal di dalamnya, hal itu dikarenakan munculnya kasus korupsi yang terjadi di gereja yang mengakibatkan turunnya kepercayaan jemaat terhadap pengelola keuangan. Padahal gereja merupakan salah satu organisasi nirlaba yang dipercaya jemaat untuk mengelola keuangan untuk tujuan spiritual. Untuk mencegah terjadinya kecurangan dan kecurigaan jemaat terhadap pengelola keuangan di dalam gereja, maka dierlukan sistem pengelolaan keuangan yang transparan dan pengendalian internal yang baik.

\subsection{Rumusan Masalah}

Berdasarkan latar belakang yang telah disampaikan, maka rumusan masalah dalam penelitian ini adalah :

1. Bagaimana sistem pengelolaan keuangan di Gereja Kristen Jawa Wedi?

2. Bagaimana akuntabilitas keuangan di Gereja Kristen Jawa Wedi?

3. Bagaimana pengendalian internal di Gereja Kristen Jawa Wedi?

\section{TINJAUAN PUSTAKA}

\subsection{Organisasi Nirlaba}

Kata organisasi berasal dari kata organization, yang memiliki arti sebagai sesuatu hal yang mengatur dan menyusun bagian - bagian yang memiliki hubungan satu sama lain, yang setiap bagiannya memiliki fungsi tersendiri sesuai kapasitasnya (Sulistyorini,2001). Secara sederhana, organisasi dappat dikatakan sebagai suatu wadah atau perserikatan kerjasama manusia yang didalamnya terdapat struktur organisasi, pembagian tugas, hak dan tanggung jawab untuk mencapai tujuan bersama

\subsection{Akuntansi}

Warren (2008:10) mengungkapkan bahwa akuntansi merupakan sistem informasi yang menghasilkan laporan kepada pihak - pihak yang mempunyai kepentingan dalam aktivitas ekonomi dan kondisi perusahaan. 


\subsection{Pernyataan Standar Akuntansi Keuangan No 45}

PSAK No 45 diciptakan dengan tujuan untuk mengatur pelaporan keuangan dalam entitas nirlaba, sehingga pelaporan keuangan entitas nirlaba lebih mudah dipahami, memiliki relevansi, dan dapat dibandingkan.Pernyataan yang terdapat dalam PSAK No 45 berlaku bagi Entitas nirlaba yang memiliki karakteristik sebagai berikut :

a. Sumber daya yang dimiliki entitas berasal dari pemberian pemberi sumber daya, yang tidak mengharapkan adanya pengembalian yang sebanding dengan pemberiannya dari entitas

b. Entitas menghasilkan barang/jasa tanpa tujuan menghasilkan laba, dan jika entitas mendapatkan laba, maka laba yang di dapatkan tidak dibagikan kepada pemilik entitas.

c. Kepemilikan dalam entitas nirlaba tidak boleh sama dengan entitas binsin, artinya kepemilikan dalam entitas nirlaba tidak dapat dijual belikan atau dialihkan seperti entitas bisnis.

Selain entitas yang memiliki karakteristik diatas, PSAK 45 dapat digunakan untuk penerintahan, dan unit lain yang tidak berlawanan dengan perundang - undang yang berlaku.IAI (2011:45) menetapkan komponen laporan keuangan organisasi nirlaba menurut PSAK no. 45, yaitu laporan posisi keuangan, laporan aktivitas, laporan arus kas dan catatan atas laporan keuangan.

\subsection{Akuntabilitas}

Akuntabilitas menurut Lembaga Administrasi Negara dan Badan Pengawasan Keuangan dan Pembangunan RI (2000:12) adalah kewajiban untuk memberikan pertanggungjawaban atau menjawab dan menerangkan kinerja dan tindakan seseorang/pimpinan suatu unit organisasi kepada pihak yang memiliki hak atau wewenang meminta pertanggungjawaban. Menurut Koopel (2005) dalam penelitiannya yang berjudul Pathologies Of Accountabilty ICANN and the Challenge of "Multiple Accountability Disorder", Public Administration Review, akuntabilitas terdiri dari lima dimensi. Lima dimensi yang dimaksud adalah transparansi, liabilitas, pengendalian, responsibilitas, dan responsivitas.

\subsection{Sistem Pengendalian Internal}

Pengendalian internal dapat diartikan sebagai rencara organisasi serta metode - metode terkait dan pengukuran yang digunakan organisasi untuk melindungi aset dari pencurian, perampokan dan penyalahgunaan oleh pihaktertentu serta meningkatkan keakuratan dan kebenaran pencatatan akuntansi (Weygandt et al. 2007:454). COSO (Picket,2003) mendefinisikan di dalam unsur - unsur pengendalian internal terdapat lima komponen, yaitu lingkungan pengendalian, penilaian resiko, aktivitas pengendalian, informasi dan komunikasi, dan monitoring.

\subsection{Penelitian Terdahulu}

1. Komang (2015) dengan judul Konsep Akuntabilitas Keuangan dalam Organisasi Keagamaan (Studi Kasus pada Gereja Kerasulan Baru di Indonesia, Distrik Jawa Timur dan Bali), penelitian ini didasari banyaknya gereja yang membuat sistem pengelolaan keuangan yang bersifat sentralistik tetapi hampit tidak ada masalah keuangan yang terkuak, dan kepercayaan jemaat terhadap keuangan gereja yang mereka sendiri tidak ikut terlibat. Berkaitan dengan hal tersebut, komang dalam penelitiannya membahas mengenai proses keuangan di Gereja Kerasulan Baru distrik Jawa Timur dan Bali, dan bagaimana sistem keuangan Gereja Kerasulan Baru distrik Jawa Timur dan Bali mampu menjamin terlaksananya pengelolaan keuangan yang akuntabel.

2. Janets (2011) melakukan penelitian terhadap akuntabilitas keuangan Gereja dengan judul Akuntabilitas dalam Perspektif Gereja Protestan (Studi Fenomenologis pada Gereja Protestan Indonesia Donggala Jemaat Manunggal Palu). Penelitian Janets bertujuan untuk mengamati serta mendeskripsikan akuntabilitas yang ada di gereja 
protestan, sehingga peneliti mampu memperoleh solusi dalam mewujudkan pelaksanaan keuangan yang baik.

3. John (1999) melakukan penelitian terhadap internal kontrol yang terdapat di Gereja yang terletak di Amerika Serikat. Penelitian John diberi judul Internal control systems in US churches, An examination of the effects of church size and denomination on systems of internal control. Tujuan penelitian ini untuk mengevaluasi efek dari ukuran gereja, kepengurusan, dan struktur demonisasi terhadap pengendalian internal Gereja.

\section{METODE PENELITIAN}

\subsection{Jenis Data}

Dalam penelitian ini penulis menggunakan data berupa data kualitatif. Didalam melakukan penelitian kualitatif, penulis diharuskan lebih fokus terhadap fenomena yang terjadi dalam kehiduan sosial, yang nantinya akan dianalisis mengguunakan teori yang sudah ada (Bambang dan Melia, 2008:78-79). Penelitian kualitatif berbeda dengan penelitian kuantitatif. Di dalam penelitian kuantitatif penulis melakukan pengukuran data kuantitatif dan statistik objektif dengan perhitungan ilmiah, sedangkan di dalam penelitian kualitatif data yang digunakan tidak berbentuk angka, data dapat berupa narasi, deskrisi, cerita, dokumen tertulis maupun tidak tertulis.

\subsection{Tempat dan Waktu Penelitian}

Didalam penelitian ini, penulis melakukan penelitian di Gerja Kristen Jawa (GKJ) Wedi yang terletak di Magersari Glodogan Klaten Selatan. Penilitian dilakukan selama empat bulan, mulai bulan November 2016 hingga Februari 2017. Penulis sendiri merupakan warga Gereja aktif di GKJ Wedi selama dua puluh tahun, sehingga memahami aktivitas yang ada di Gereja.

\subsection{Sumber Data}

Didalam penelitian ini penulis menggunakan dua jenis sumber data. Yaitu :

1. Data Primer

Data primer merupakan data - data yang diperoleh penulis secara langsung dari pihak GKJ Wedi Klaten yang berkaitan dengan pengelolaan keuangan, pencatatan, akuntabilitas, pengendalian internal dan data - data lain yang berkaitan dengan penelitian.

2. Data Sekunder

Data sekunder merupakan data penunjang yang diperoleh dengan mengumpulkan informasi dari sumber - sumber lain yang berhubungan dengan penelitian.

\subsection{Metode Pengumpulan Data}

Teknik pengumpulan data yang digunakan dalam penelitian ini adalah :

1. Observasi Terus Terang

Peneliti berterus terang pada pemberi data bahwa peneliti sedang melakukan pengumulan untuk penelitian data. Sementara dalam suatu waktu peneliti tidak berterus terang kepada nara sumber.

2. Wawancara Tak Terstruktur

Yang dimaksud dengan wawancara tak terstruktur adalah wawancara yang bersifat bebas, dimana peneliti tidak menggunakan pedoman dalam melakukan wawancara dan pedoman dalam melakukan wawancara hanya berupa garis besar permasalahan.

3. Studi Pustaka

Penulis mengumpulkan data berdasar literatur yang dapat berupa buku - buku, dokumen, maupun catatan lain yang memiliki hubungan dengan penelitian.

\subsection{Teknik Analisis Data}

Penulis didalam menganalisi data menggunakan teknik analisis interaktif seperti yang dikemukakan oleh Miles dan Huberman (1992) dalam Sugiyono (2009: 92-99), yaitu: 
1. Reduksi data (data reduction)

Yang dimaksud dengan reduksi data adalah proses pemilihsn, pemusatan, penyederhanaan, dan mentranformasi data yang didapatkan dari lapangan. Proses reduksi data dilakukan penulis berlangsung terus menerus selama penulis melakukan penelitian di GKJ Wedi.

2. Penyajian Data (data display)

Penyajian data merupakan proses penyusunan data ke dalam bentuk sistematis, membuat data menjati lebih sederhana dan selektif sehingga memungkinkan adanya penarikan kesimpulan.

3. Menarik Kesimpulan (verifikasi)

Tahapan akhir dalam analisis data adalah penarikan kesimpulan. Dari proses analisis yang dilakukan penulis di GKJ Wedi, penulis berusaha menarik kesimpulan. Kesimpulan dalam data kualitatif bersifat sementara, sewaktu- waktu dapat berubah jika ditemukan data yang baru.

\section{PEMBAHASAN}

\subsection{Gambaran Umum Perusahaan}

Objek dari penelitian ini adalah Gereja Kristen Jawa (GKJ) Wedi yang terletak di Magersari No.16,RT.01 RW.01, Glodogan, Klaten. GKJ Wedi merupakan salah satu Gereja terbesar di Klaten dengan jumlah jemaat 1422 warga dan memiliki satu gereja induk dan dan lima Gereja cabang yang biasa disebut Gereja Pepanthan. GKJ Wedi juga memilik depan blok, blok merupakan pembagian wilayah yang mempermudah dalam menjalankan pelayanan agar lebih efektif.

\subsection{Organisasi GKJ Wedi}

GKJ Wedi dalam menjalankan organisasi menganut sistem pemerintahan Presbyterial Sinodal seperti GKJ pada umumnya. Pemerintahan Presbyterial Sinodal berarti kepemimpinan Gereja diegang oleh orang - orang yang dituakan, dan Gereja masih terikat dengan Gereja Kristen Jawa yang lain. Karena Gereja menganut sistem pemerintahan Presbyterial, para presbyter atau dalam hal ini adalah Majelis Gereja mempunyai wewenang untuk mengatur, memimpin, memerintah, mengembalakan dan memelihara jemaat.

Majelis Gereja terdiri dari Pendeta, Penatua dan Diaken memiliki tugas untuk mengemban tritugas Gereja, yaitu persekutuan, pelayanan, dan kesaksian. (koinonia,diakonia, dan marturia). Majelis Gereja secara keseluruhan disebut dengan Majelis Pleno atau Majelis Lengkap yang melaksanakan tugas dan kewajiban secara umum. Untuk mengontrol agar kegiatan harian Gereja sesuai dengan ajaran Gereja dan keputusan Sidang Majelis Pleno, maka Gereja membentuk Majelis Harian yang terdiri dari ketua 1, ketua 2, sekretaris 1, sekretaris 2, bendahara 1, bendahara 2, koordinator bidang ibadah, koordinator bidang pembinaan warga gereja (PWG), koordinator bidang kesaksian dan pelayanan (KesPel), koordinator bidang sarana dan prasarana (SarPras).

Untuk menjalankan tritugas Gereja, Majelis GKJ Wedi dibagi menjadi empat Majelis Bidang yang membawahi Komisi - komisi Gereja dan majelis pepanthan yang mewakili setiap pepanthan. Empat Majelis Bidang yang ada di GKJ Wedi antara lain :

1. Majelis Bidang Ibadah

Majelis Bidang Ibadah membawahi tiga Komisi Gereja, yaitu :

a. Komisi Peribadatan

b. Komisi Konseling dan Doa

c. Komisi Kesenian

2. Majelis Bidang Pembinaan Warga Gereja

Majelis Bidang Pembinaan Warga Gereja membawahi empat Komisi Gereja, yaitu :

a. Komisi Anak

b. Komisi Pemuda Remaja 
c. Komisi Warga Dewasa

d. Komisi Adiyuswa

3. Majelis Bidang Kesaksian dan Pelayanan

Majelis Bidang Kesaksian dan Pelayanan membawahi empat Komisi Gereja, yaitu :
a. Komisi Pendidikan
b. Komisi Pralenan
c. Komisi Pengembangan Ekonomi Jemaat (PEJ)
d. Komisi Kesehatan

4. Majelis Bidang Sarana - Prasarana

Majelis Bidang Sarana - Prasarana membawahi dua Komisi Gereja, yaitu :

a. Komisi Aset dan Harta Benda

b. Komisi Rumah Tangga Pendeta dan Karyawan Gereja

Selain komisi yang telah disebutkan sebelumnya, Gereja membentuk tim pemeriksa keuangan, membentuk tim kajian, pengembangan, pengkaderan, dan komisi keuangan yang bertanggung jawab kepada bendahara Gereja. Setiap Majelis Bidang dan Majelis Pepanthan mempertanggungjawabkan tugas yang dijalankan kepada Majelis Harian.

Untuk menyelesaikan permasalahan administrasi, di dalam Gereja terdapat kantor Gereja yang didalamnya terdiri dari tenaga akuntansi dan koster. Kantor Gereja dalam menjalankan tugas bertanggung jawab langsung kepada Majelis Pleno.

Gambar 4.1

Struktur Organisasi GKJ Wedi

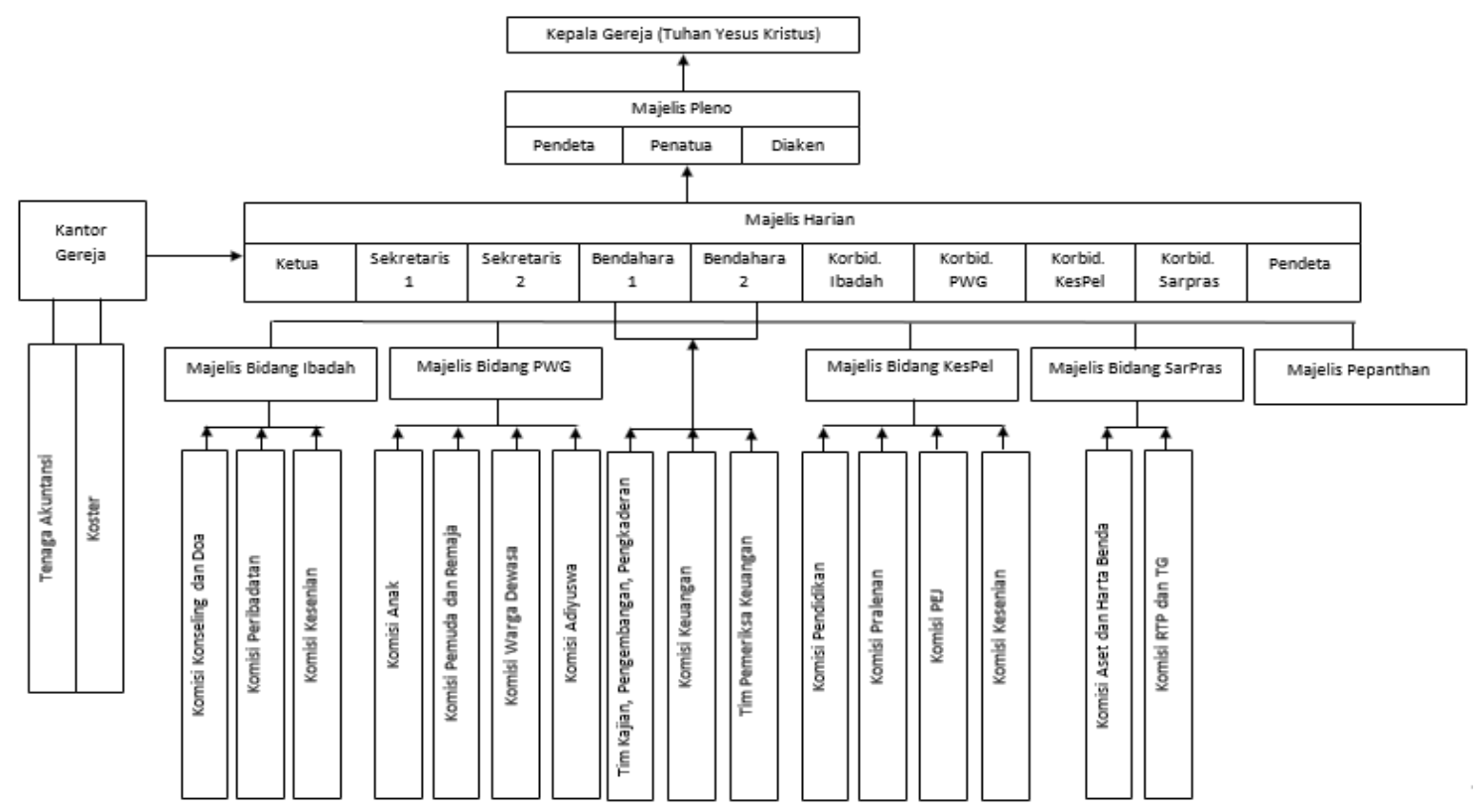

\subsection{Penerapan Akuntansi GKJ Wedi}

Berdasarkan pengamatan yang dilakukan, GKJ Wedi hanya melakukan pencatatan dan pelaporan terhadap kas saja, tidak melakukan pencatatan dan pelaporan aset yang lain seperti bangunan dan kendaraan. Kegiatan akuntasi di GKJ Wedi Meliputi :

1) pengajuan program kerja berserta anggaran selama satu tahun dari komisi;

2) pembuatan anggaran gereja selama satu tahun;

3) pembuatan laporan bulanan GKJ Wedi;

4) pembuatan laporan realisasi anggaran. 
Pemasukan utama GKJ Wedi di dapat dari persembahan yang diberikan oleh jemaat dan pendapatan yang lain seperti hibah. Pemasukan yang di dapat oleh gereja kemudian digunakan untuk membiayai kegiatan yang dilakukan oleh gereja. Pemasukan yang terima gereja terdiri dari :

1. Persembahan mingguan

2. Persembahan bulanan

3. Persembahan sakramen

4. Persembahan kebaktian hari raya gerejawi

5. Persembahan kebaktian khusus

6. Persembahan istimewa

7. Masa Paskah, Pentakosta, Bulan Keluaga, Advent, Pepenkris

8. Iuran pensiun

9. Penuaian

10. Persembahan lain - lain

11. Kayekten dan Dilah

12. Persembahan khusus

Setiap pemasukan yang diterima oleh gereja digunakan untuk membiayai kegiatan gereja dalam melayani. Pengeluaran GKJ Wedi di bagi menjadi beberapa kategori, yaitu :

1. Biaya Hidup Tenaga Kerja

2. Tunjangan Tenaga Kerja

3. Kebutuhan Majelis

4. Biaya tak terduga

5. Biaya lain - lain

\subsection{Pelaporan Keuangan GKJ Wedi}

Pelaporan keuangan merupakan hal penting bagi entitas. Laporan keuangan memberikan informasi mengenai kinerja entias selama satu periode dan keadan entitas yang terkait. Laporan keuangan GKJ Wedi dibuat oleh komisi keuangan dan terddiri dari laporan bulanan dan tahunan.

a. Laporan bulanan GKJ Wedi

Laporan bulanan merupakan laporan keuangan yang diterbitkan setiap bulan. Laporan bulanan berisi laporan keuangan bulanan yang berupa laporan kas masuk dan keluar pada bulan yang bersangkutan, rekapitulasi uang hari raya penuaian, keterangan pengeluaran pepantan bulanan, rekapitulasi uang jemaat, dan laporan kartu persembahan. Laporan bulanan dibuat oleh komisi keuangan berdasarkan laporan majelis pada rapat harian.

b. Laporan tahunan GKJ Wedi

Laporan tahunan GKJ Wedi berupa buku berjudul Materi Sidang Majelis Terbuka GKJ Wedi yang juga digunakan sebagai acuan dalam sidang terbuka.

\subsection{Evaluasi Penerapan Akuntansi Pada GKJ Wedi}

Gereja dalam menerapkan akuntasi sudah berjalan cukup baik, karena akuntansi yang diterapkan sudah mampu memenuhi kebutuhan Gereja. Tetapi akan lebih baik apabila akuntansi di GKJ Wedi sesuai dengan standar yang ada, khususnya dalam hal pelaporan keuangan. Pelaporan keuangan dalam GKJ Wedi sebaiknya sesuai dengan PSAK No.45. Dengan diterapkannya pelaporan keuangan sesuai dengan PSAK No.45 akan membantu Gereja dalam memberikan informasi yang lebih lengkap bagi pihak yang membutuhkan. Pelaporan keuangan Gereja saat ini hanya dapat memberikan informasi mengenai kas yang masuk dan kelua. Jika GKJ Wedi menggunakan pelaporan keuangan sesuai dengan PSAK No.45 , GKJ Wedi dapat memberikan informasi tidak hanya berkaitan dengan kas masuk dan keluar, tetapi juga mengenai jumlah aset, jumlah kewajiban, dan aktivitas apa saja yang dilakukan oleh Gereja dalam satu periode. Selain pelaporan keuangan yang sesuai dengan standar, penulis juga meminta Gereja agar lebih memerhatikan dalam mengelompokkan pengeluaran dan pemasukan. Pada tahun 2015 ditemukan pengeluaran yang tak terduga dengan nominal yang cukup besar, hal ini dikarenakan di dalam pengeluaran tak terduga terdapat pengeluaran untuk membantu dalam pembangunan gedung Gereja Pepanthan, dan 
bantuan pengadaan kendaraan bagi Pendeta. Pengeluaran untuk bantuan pembangunan dan pengadaan motor seharusnya dapat dianggarkan telebih dahulu, dan kelompok pengeluaran tidak terduga berisi pengeluaran yang benar - benar tidak di duga seperti kebakaran.

\subsection{Perapan Akuntabilitas di GKJ Wedi}

Penerapan akuntabilitas GKJ Wedi sesuai dengan dimensi akuntabilitas menurut Koopel (2005) adalah :

1. Transparansi

Transparansi merupakan nilai utama dari akuntabilitas, karena transparansi merupakan wujud keterbukaan agensi terhadap prinsipal. Gereja menginformasikan kinerja yang dilakukan kepada jemaat selaku pemberi dana dengan beberapa cara, yaitu pengadaan Warta Gereja, Warta Gereja merupakan pengumuman yang diberikan Gereja setiap minggu, warta Gereja disampaikan secara lisan maupun tertulis. Warta Gereja berisi informasi kegiatan yang dilakukan Gereja dan pemasukan yang diterima dari jemaat pada ibadah sebelumnya, dan pemasukan yang diterima Gereja selama satu bulan. Selain Warta Gereja, Gereja juga mengadakan Rapat harian. Rapat harian merupakan rapat yang diadakan Gereja setiap sebulan sekali. Rapat harian dihadiri oleh seluruh Majelis yang ada. Dalam rapat ini, setiap majelis melaporkan pemasukan dan pengeluaran Gereja selama satu bulan dan dicatat oleh komisi keuangan. Setelah proses pencatatan, komisi keuangan berkewajiban melaporkan setiap hasil pencatatan kepada semua majelis selaku wakil dari jemaat berupa laporan keuangan bulanan. Terakhir adalah Sidang Terbuka,Sidang Terbuka merupakan rapat yang diadakan oleh Gereja setiap akhir tahun. Sidang terbuka dapat diikuti oleh seluruh warga gereja, baik itu majelis maupun jemaat pada umumnya. Sidang Terbuka membahas kinerja Gereja selama satu tahun, dan rencana kerja Gereja pada tahun berikutnya.

2. Liabilitas

Liabilitas yang dimaksud Koopel dalam unsur akuntabilitas adalah konsepsi mengenai pemberian reward maupun hukuman kepada individu, untuk tindakan yang mereka lakukan. Setelah dilakukan wawancara dan observasi, konsep liabilitas tidak berjalan dalam proses pengelolaan keuangan GKJ Wedi. Hal ini dikarenakan, seluruh tindakan yang dilakukan oleh individu di dalam Gereja dipertanggungjawabkan bukan hanya kepada majelis, tetapi dipertanggungjawabkan kepada Tuhan sebagai pimpinan Gereja

3. Pengendalian

Didalam GKJ Wedi, kontrol dilakukan dengan beberapa cara. Yang pertama dengan adanya alur pertanggungjawaban. Setiap aktivitas yang dilakukan oleh komisi akan diertanggungjawabkan kepada koordinator tiap komisi, tiap koordinator tiap komisi akan memberikan pertanggungjawaban kepada majelis harian. Selain dengan alur pertanggungjawaban, Gereja melakukan pengendalian dengan adanya anggaran. Setiap aktivitas yang dilakukan Gereja harus sesuai dengan anggaran yang ditetapkan pada awal tahun.

4. Responsibilitas dan Responsivitas

Responsibilitas mengharuskan penggunaan keahlian yang dibatasi oleh standar profesional dan moral. Mengacu pada hal tersebut, responsibilitas GKJ Wedi belum terlaksana dengan baik. Karena dalam mengelola keuangan, Gereja tidak melakukan pengelola keuangan sesuai dengan standar yang ada. Hal ini dapat dilihat dari ketidak sesuaian antara laporan keuangan Gereja dengan standar yang ada, yaitu PSAK No 45.

Responsivitas berkaitan dengan kemampuan Gereja memenuhi kebutuhan dan kepentingan prinsipal, dalam hal ini adalah jemaat dan Tuhan. Agar kebutuhan dan kepentingan jemaat dan Tuhan terlaksana, maka kinerja Gereja didasarkan pada anggaran yang kegiatan didalamnya didasari Firman Tuhan.

\subsection{Evaluasi Penerapan Akuntabilitas di GKJ Wedi}

Akuntabilitas di dalam GKJ Wedi sudah berjalan dengan baik, hal ini dapat dilihat dari berbagai tindakan yang dilakukan Gereja untuk mewujudkan pengelolaan keuangan yang transparan. Upaya yang dilakukan Gereja berupa pengadaan warta Gereja 
setiap minggu, yang menginformasikan jumlah pemasukan yang diterima Gereja pada ibadah. Selain itu, Gereja juga menginformasikan pemasukan dan pengeluaran Gereja secara rutin melalui rapat Majelis. pengendalian di dalam GKJ Wedi juga sudah berjal an dengan baik, hal ini dapat dilihat dengan adanya anggaran. Setiap pengeluaran yang dilakukan oleh Gereja harus sesuai dengan anggaran yang dibuat pada awal periode.

Dalam penerapan akuntabilitas, GKJ Wedi masih memiliki beberapa kekurangan. Kekurangannya yaitu, laporan keuangan yang dibuat oleh GKJ Wedi hanya sebatas pemasukan dan pengeluaran kas, dan tidak sesuai dengan PSAK 45. Hal tersebut mengakibatkan Gereja tidak dapat mengetahui dan menyampaikan nilai aset yang dimiliki Gereja selain kas, seperti gedung, kendaraan, dan komputer. Kekurangan yang kedua adalah tidak adanya penghargaan bagi pengelola dalam menjalankan tugasnya. Padahal, dengan adanya penghargaan, dapat memotivasi pengelola dalam menjalankan tugasnya.

\subsection{Sistem Pengendalian Internal GKJ Wedi}

Sistem pengendalian internal menurut Coso (2013) adalah sebagai berikut :

1. Lingkungan Pengendalian

Dalam GKJ Wedi, lingkungan pengendalian sudah berjalan dengan baik, walaupun masih terdapat beberapa kekurangan. Struktur organisasi di GKJ Wedi sudah disusun dengan baik, hal ini dapat dilihat dengan adanya pembagian tanggungjawab yang jelas. Pengelola di dalam Gereja juga memiliki etika yang baik, karena pengelola percaya tugas mereka bukan hanya untuk manusia tetapi juga untuk memuliakan nama Tuhan. Kekurangan yang ada dalam lingkungan pengendalian GKJ Wedi adalah pengelola kurang berkompeten dalam bidangnya, sehingga pengelola tidak dapat menjalankan tugas dengan maksimal, dan juga terdapat pembagian tugas yang kurang baik, khusunya dalam bagian keuangan.

2. Penilaian Resiko

Penilain resiko yang ada di GKJ Wedi sudah berjalan dengan baik, pihak pengelola sudah memahami resiko yang mungkin akan terjadi dan membentuk aktivitas -aktivitas yang mengurangi kemungkinan terjadinya resiko tersebut. Untuk mengatasi hal tersebut, pihak Gereja mewajibkan setiap komisi mengajukan rencana kegiatan dan anggaran, agar setiap kegiatan yang ada dapat dipantau. Dan dengan pengajuan rencana kegiatan, dapat mencegah adanya perbedaan tujuan antara komisi dengan Gereja.

3. Aktivitas Pengendalian

Dalam aktivitas pengendalian, GKJ Wedi sudah melaksanakan dengan baik. Hal ini dapat dilihat dengan adanya otorisasi, pembagian tanggung jawab dan dokumen untuk setiap transaksi. Adanya otorisasi di GKJ Wedi dibuktikan dalam pembuatan rencana kerja setiap komisi. Setiap rencana kerja dan anggaran setiap komisi harus disetujui terlebih dahulu oleh Majelis Pendamping setiap komisi, dan koordinator bidang yang bertanggungjawab. Sedangkan dokumen dapat dilihat dengan adanya buku laporan bulanan yang berisi bukti kas masuk dan keluar setiap bulannya.

4. Informasi dan Komunikasi

Sistem informasi dan komunikasi di GKJ Wedi sudah berjalan dengan cukup baik, hal ini dapat dilihat dengan adanya prosedur, dan pemberian tanggungjawab yang jelas. Pihak yang bertanggungjawab mencatat, dan membuat laporan mengenai keuangan Gereja adalah Komisi Keuangan. Setiap catatan dan laporan keuangan yang dibuat juga harus disertai bukti dan persetujuan dari pihak yang yang bertanggungjawab.

5. Monitoring

Monitoring dilakukan agar dapat membantu manajer mengetahui ketidakefektifan pelaksanaan unsur - unsur pengendalian yang lain. GKJ Wedi melakukan pemantauan dengan cara evaluasi, agar penyimpangan yang ditemukan dapat ditanggapi dengan baik dan mencerminkan adanya kesadaran mengenai pentingnya pengendalian yang tertanam dalam diri pengelola. 


\subsection{Sistem dan ProsedurPemasukan dan Pengeluaran Kas GKJ Wedi}

\section{Sistem dan Prosedur Pemasukan GKJ Wedi}

Di dalam penerimaan kas, GKJ Wedi memiliki prosedur sebagai berikut:

a. Persembahan yang diterima Gereja dikumpulkan oleh anggota Komisi Keuangan Gereja yang ada di Gereja Penpanthan maupun Gereja Induk.

b. Setiap anggota Komisi Keuangan Gereja yang mengumpulkan persembahan dari Gereja Penpanthan maupun Induk menyetorkan persembahan yang dikumpulkan pada rapat Komisi Keuangan.

c. Persembahan yang terkumpul dalam rapat Komisi Keuangan disetorkan kepada Bendahara Gereja untuk disimpan.

\section{Sistem dan Prosedur Pengeluaran GKJ Wedi}

Di dalam melakukan pengeluaran, GKJ Wedi memiliki prosedur sebagai berikut:

a. Komisi atau Majelis yang bersangkutan membuat surat permohonan dana yang diajukan kepada Majelis Pleno. Surat permohonan yang diajukan harus sesuai dengan anggaran yang diajukan komisi atau majelis pada awal tahun, dan seandainya ada perbedaan maka harus terdapat alasan yang jelas.

b. Majelis Pleno melakukan pembahasan mengenai surat permohonan dana dari komisi atau majelis pada rapat Majelis Pleno.

c. Surat permohonan dana yang telah disetujui akan dilaporkan kepada Bendahara Gereja, agar Benndahara Geraja menyiapkan dana yang diminta.

d. Komisi atau Majelis yang bersangkutan mengambil dana yang diminta kepada Bendahara Gereja.

Gambar 4.2

Flowchat Proses Kas Masuk GKJ Wedi

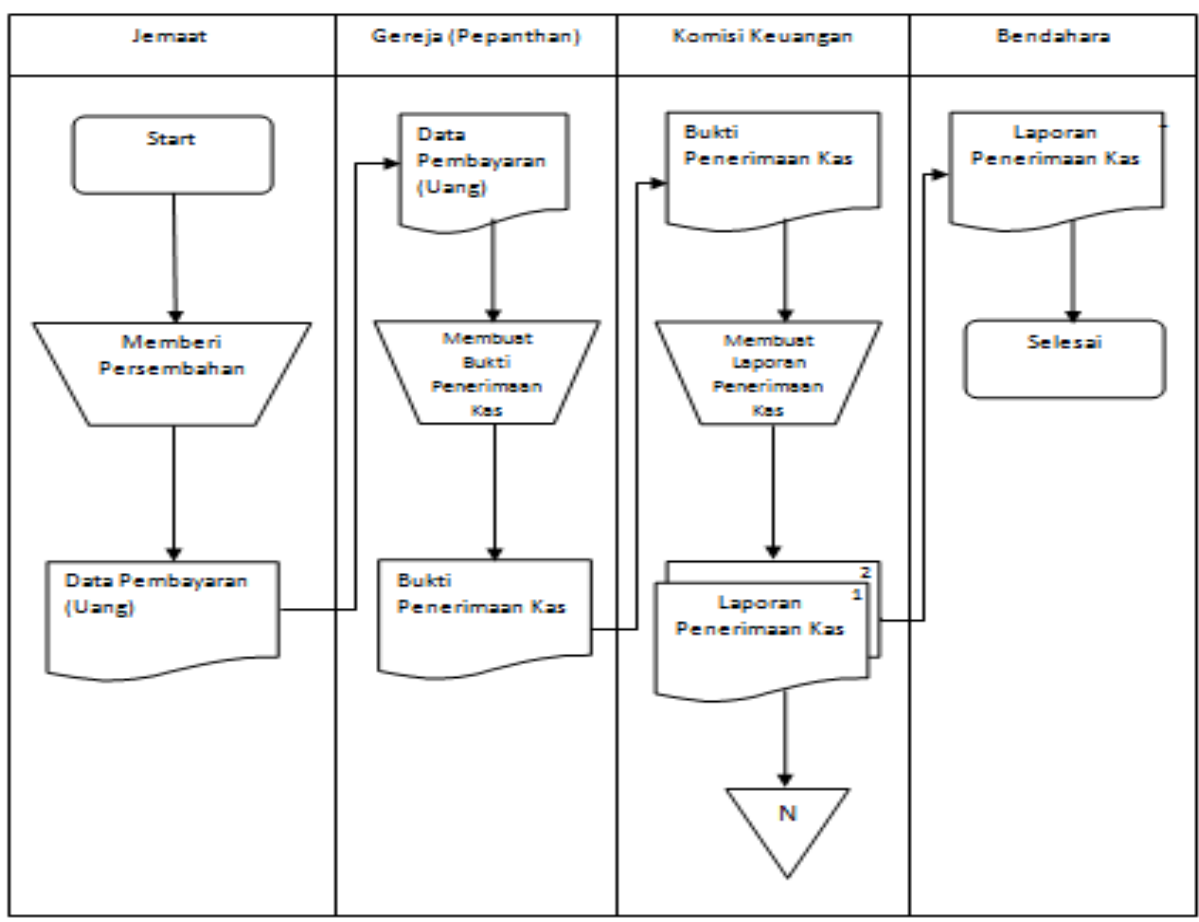


Gambar 4.4

Flowchart Proses Kas Keluaar

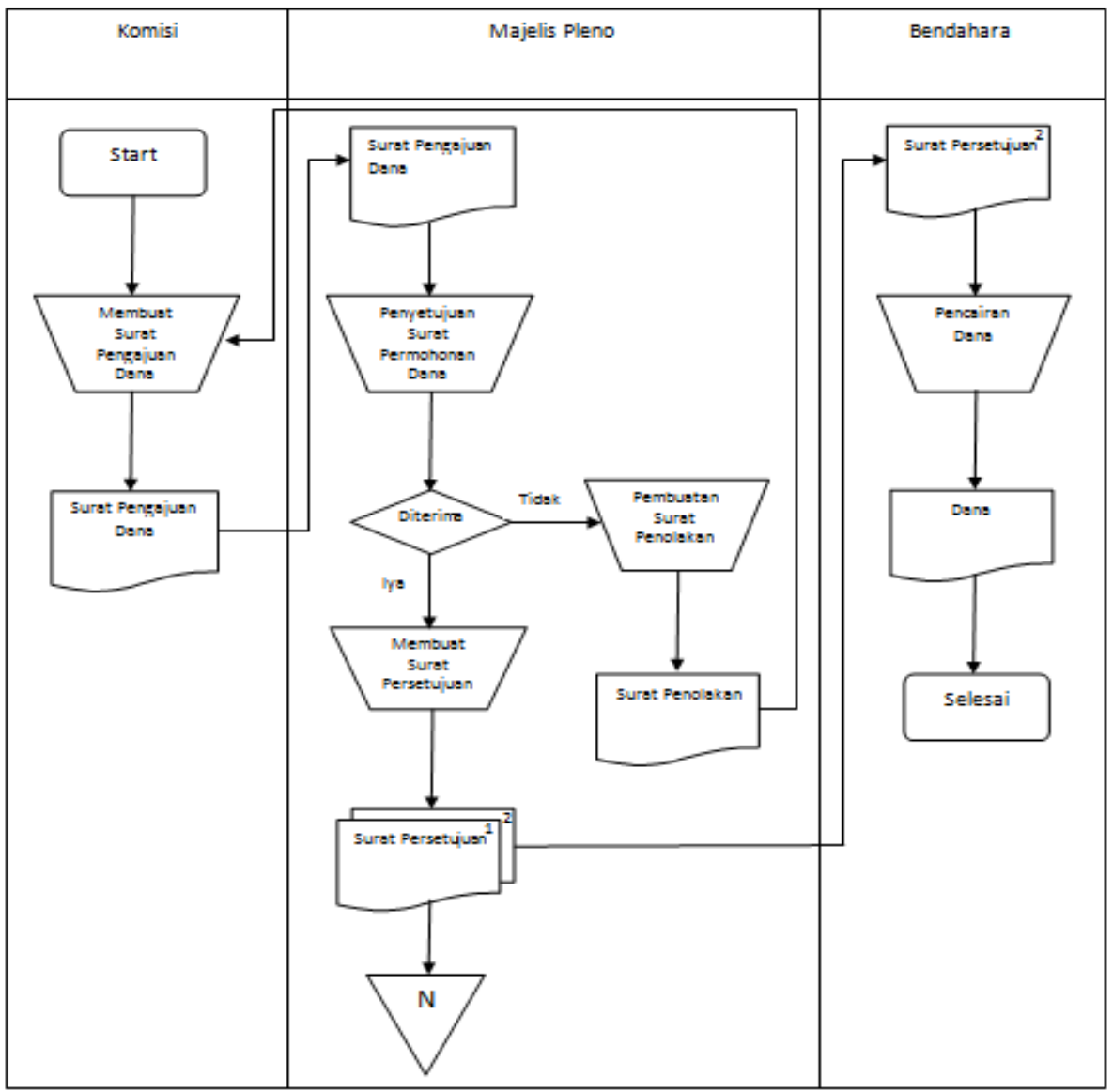

Gambar 4.4

Penjelasan Simbol Flowchart Proses Kas Masuk dan Keluar GKJ Wedi

\begin{tabular}{|c|c|c|}
\hline Simbol & Nama & Penjelasan \\
\hline & Terminal & Awal atau akhir dari suatu program \\
\hline & Dokumen & Dokumen atau laporan \\
\hline & $\begin{array}{l}\text { Salinan dari satu } \\
\text { dokumen }\end{array}$ & $\begin{array}{l}\text { Satu dokumen di salin menjadi } \\
\text { beberapa lembar }\end{array}$ \\
\hline & Operasi Manual & Proses yang dilakukan secara manual \\
\hline & File & $\begin{array}{l}\text { File dari dokumen yang disimpan } \\
\text { secara manual }\end{array}$ \\
\hline & Keputusan & $\begin{array}{l}\text { Memutuskan untuk langkah } \\
\text { selanjutnya }\end{array}$ \\
\hline & $\begin{array}{l}\text { Alur Dokumen atau } \\
\text { Proses }\end{array}$ & $\begin{array}{l}\text { Arah alur suatu proses atau } \\
\text { dokumen }\end{array}$ \\
\hline
\end{tabular}




\subsection{Proses Pemeriksaan Keuangan GKJ Wedi}

Dalam melakukan pemeriksaan keuangan Gereja, terdapat proses sebagai berikut :

1. Tim Pemeriksaan Keuangan mengadakan rapat mengenai waktu dan tempat pelaksanaan pemeriksaan keuangan.

2. Setelah diadakan rapat, hasil rapat berupa usulan waktu dan tempat pelaksanaan pemeriksaan keuangan diserahkan kepada Majelis Pleno.

3. Setelah disetujui oleh Majelis Pleno, Gereja membuat surat undangan yang ditujukan kepada pihak yang akan diperiksa. (Bendahara, Majelis yang bersangkutan, dan Komisi)

4. Pada hari pelaksanaan, pihak yang bersangkutan memberikan realisasi anggaran selama satu periode beserta bukti kas masuk dan keluar.

5. Tim Pemeriksa Keuangan mencocokkan pemasukan dan pengeluaran dengan bukti yang ada.

6. Setelah melakukan pemeriksaan, Tim Pemeriksa Keuangan memberikan hasil pemeriksaan berupa berita acara. Hasil dapat berupa baik, baik dengan ketentuan khusus seperti beberapara bukti belum ada, dan tidak baik.

\subsection{Evaluasi Pengendalian Internal GKJ Wedi}

Pengendalian internal di GKJ Wedi memiliki kelebihan dan kekurangan. Kelebihan dari pengendalian internal di GKJ Wedi adalah, yang pertama adanya pemisahan tanggung jawab yang jelas, sehingga tugas yang ada dapat dijalankan dengan lebih efisien. Yang kedua, setiap pemasukan dan pengeluaran yang terjadi harus disertai bukti dokumen seperti kwitansi, sehingga dapat meminimalisiri kecurangan. Ketiga, adanya tim pemeriksaan keuangan yang bertugas untuk mengawasi dan mengevaluasi keuangan Gereja, sehingga jika terdapat pemasukan dan pengeluaran yang tidak wajar dapat segera diketahui.

Kekurangan dari pengendalian internal GKJ Wedi adalah di dalam lingkungan pengendalian, pengelola dalam GKJ wedi tidak kompeten sehingga memungkinkan terjadinya kesalahan. Kedua, tidak adanya pemisahan tugas dalam beberapa bagian. Hal ini dapat dilihat dari kewenangan bendahara untuk menyimpan dan mencatat keuangan Gereja, sehingga memungkinkan terjadinya kecurangan.

Untuk meningkatkan pengendalian internal GKJ Wedi, penulis menyarankan pengelola GKJ Wedi agar merekrut tenaga ahlli untuk membantu dalam mengelola keuangan GKJ Wedi, dan melakukan pemisahan tugas, khususnya dalam bagian - bagian yang memungkinkan terjadinya kecurangan, seperti pada pencatatan dan penyimpanan kas Gereja.

\section{PENUTUP}

\subsection{Kesimpulan}

Berdasarkan hasil analisa terhadap penerapan akuntansi, akuntabilitas dan pengendalian internal yang dilakukan di GKJ Wedi maka penulis menyimpulkan bahwa :

1. Kegiatan akuntansi, akuntabilitas dan pengendalian internal pada GKJ Wedi sudah berjalan dengan baik walaupun belum sesuai dengan standar yang ada, yaitu PSAK No 45 .

2. Terdapat perbedaan antara laporan keuangan GKJ Wedi dengan PSAK 45, diantaranyalaporan keuangan GKJ Wedi berupa laporan keuangan bulanan dan laporan keuangan tahunan, laporan keuangan yang dibuat hanya menginformasikan pengeluaran dan pemasukan yang diterima oleh Gereja, tidak menginformasikan mengenai nilai aset selain kas. Sedangkan menurut standar, laporan keuangan organisasi nirlaba terdiri dari laporan posisi keuangan, laporan laba rugi, laporan perubahan equitas, laporan arus kas dan catatan atas laporan keuangan.

3. GKJ Wedi sudah menerapkan akuntabilitas dengan cukup baik, hal ini dapat dilihat dari terpenuhinya aspek transparansi, liabilitas, kontrol, dan responsivitas.

4. Pengendalian internal dalam GKJ Wedi sudah berjalan dengan baik, sehingga mampu mengurangi kemungkinan terjadi kecurangan, walaupun terdapat beberapa prosedur yang belum terlaksana dengan baik seperti lingkungan pengendalian, dimana karywan 
yang mengelola kurang berkompeten, dapat diandalkan, dan etis serta kurangnya aktivitas pengendalian karena belum adanya pemisahaan tugas di beberapa bagian.

\subsection{Saran}

Penulis memiliki beberapa saran terhadap GKJ Wedi, yaitu :

1. GKJ Wedi sebaiknya membuat laporan keuangan sesuai dengan PSAK 45, sehingga laporan keuangan yang disajikan oleh gereja dalam laporan keuangan lebih jelas, relevan, dapat dipercaya dan transparan dalam pelaporannya.

2. GKJ Wedi lebih memperhatikan dalam mengelompokkan pemasukan dan pengeluaran, agar tidak terjadi kesalahan seperti pada pengeluaran tidak terduga yang mengakibatkan pengeluaran tidak terduga menjadi tidak wajar.

3. GKJ Wedi memerlukan adanya tenaga ahli untuk membantu dalam mengelola keuangan dan pemeriksaan internal sehingga, sehingga keuangan Gereja lebih akuntabel dan dapat dipercaya.

4. Gereja perlu melakukan pemisahan tugas dan tanggung jawab, orang yang memiliki tugas menyimpan uang Gereja tidak boleh sama dengan orang yang bertugas melakukan pencatatan. Hal ini dapat meminimalisir terjadi penyalahgunaan uang Gereja.

\section{DAFTAR PUSTAKA}

Abraham Hauriasi Karen Van-Peursem Howard Davey .(2016)."Budget processes in the Anglican Church of Melanesia: an emergent ethnic identity". Accounting, Auditing \& Accountability Journal. Vol. 29 Iss 8 pp. 1294 - 1319

Catriona Paisey Nicholas J. Paisey. (2011)."Visibility, governance and social context". Accounting, Auditing \& Accountability Journal. Vol. 24 Iss 5 pp. 587 - 621

Dewi, Atmadja, dan Addiputra.(2015). "Konsep Akuntabilitas Keuangan Dalam Organisasi Keagamaan (Studi Kasus pada Gereja Kerasulan Baru di Indonesia, Distrik Jawa Timur dan Bali)". e-Journal S1 Ak Universitas Pendidikan Ganesha Jurusan Akuntansi Program S1 (Volume 3 No 1 Tahun 2015).

Ely Suhayati dan Sri Dewi Anggadini. (2005). Pengantar Akuntansi I. Bandung: UNIKOM.

Ermansjah Djaja. (2010). Memberantas Korupsi Bersama KPK. Jakarta: Sinar Grafika.

Fransiskus, R. et al.(2011)."Studi Etnografi:Akuntabilitas Spiritual Pada Organisasi Gereja Katolik yang Terinkulturasi Budaya Lokal". Vol.2 no 12

Funnell Warwick Williams Robert. (2014)."The religious imperative of cost accounting in the early industrial revolution". Accounting, Auditing \& Accountability Journal. Vol. 27 Iss 2 pp. $357-381$

Gavriel, I. (2013). Skandal “Gereja Bethany” Surabaya, Pendeta Gelapkan Dana Gereja 4,7 Trilliun Terancam Penjara: Detiknews [Online]. Tersedia: http://www.deliknews.com/2013/02/27/skandal-gereja-bethany-surabaya-pendetagelapkan-dana-gereja-47-trilliun-terancam-penjara/ [08 November 2016].

H. Lili M. Sadeli. (2009). Dasar-Dasar Akuntans. Jakarta: PT Bumi Aksara.

Helen Irvine, (2005),"Balancing money and mission in a local church budget", Accounting, Auditing \& Accountability Journal, Vol. 18 Iss 2 pp. 211 - 237

Horngren, Harrison. (2007) .Akuntansi Edisi Ke-7.Jakarta: Penerbit Erlangga.

Ikatan Akuntan Indonesia.(2009). Standar Akuntansi Keuangan revisi 2009. Jakarta:Salemba Empat. 
John B. Duncan Dale L. FlesherMorris H. Stocks. (1999)."Internal control systems in US churches". Accounting, Auditing \& Accountability Journal, Vol. 12 Iss 2 pp. 142 - 164

Jonathan, Koppel. (2005)."Pathologies Of Accountabilty ICANN and the Challenge of Multiple Accountability Disorder". Public Administration Review. Vol. 65 No. 1.

Levita, P.L.(2015).Analisis Penerapan Akuntansi Organisasi Nirlaba Entitas Gereja Berdasarkan Pernyataan Standar Akuntansi Keuangan No.45 (Studi Kasus Gereja Masehi Injili di Minahasa Baitel Kolongan).Tugas Akhir pada Kementrian Riset Teknologi dan Pendidikan Tinggi Negeri Manado.

Mechos, D.L. (2015). Korusi Uang Gereja, Pendeta Ini Dipenjara 8 Tahun: Tempo [Online]. Tersedia: https://m.tempo.co/read/news/2015/11/21/118720890/korupsi-uang-gerejapendeta-ini-dipenjara-8-tahun. [08 November 2016].

Merystika Kabuhung.(2013)."Sistem Informasi Akuntansi Penerimaan dan Pengeluaran Kas untuk Perencanaan dan Pengendalian Keuangan Pada Organisasi Nirlaba Keagamaan”. EMBA. Vol 1 No 3. 339-348.

Moleong, L.J. (2005). Metodologi Penelitian Kualitatif. Edisi Revisi. Bandung: PT Remaja Rosdakarya.

Mulyadi. (2014). Audit 1. Edisi ke-6. Jakarta: Salemba Empat.

Mulyadi. (2014). Audit 2. Edisi ke-6. Jakarta: Salemba Empat.

Onny S, Priyono dan A. M. W. Pranarka (1996). Pemberdayaan : Konsep Kebijakan dan Implementasi. Jakarta: CSIS.

Peter Booth. (1993)."Accounting in Churches: A Research Framework and Agenda". Accounting, Auditing \& Accountability Journal. Vol. 6 Iss 4 pp.

Pontoh,C.R. (2013)."Penerapan Laporan Keuangan Organsisasi Nirlaba Berdasarkan PSAK No.45 Pada Gereja BZL". ISSN.2303-1174.

Rmc. (2013). Pdt Abraham Alex Dilaporkan Gelapkan Dana Rp 4,7 T: Surabaya Pagi.com [Online].Tersedia:

http://www.surabayapagi.com/index.php?3b1ca0a43b79bdfd9f9305b812982962d2b1298f 73a79b173c34553b88860696. [08 November 2016].

Rudito, Bambang dan Famiola. (2008). SocialMapping. Bandung: PT. Rekayasa Sains.

Sawyer. (2005). Internal Auditing. Jakarta: Salemba Empat.

Silvia dan Ansar. (2011)"Akuntabilitas Dalam Prespektif Gereja Protestan (Studi Fenomenalogis Pada Gereja Protestan Indonesia Dongala Jemaat Manunggal Palu)". Simposium Nasional Akuntansi XIV Aceh 2011.

Simanjuntak, dan Januarsi.(2011)."Akuntabilitas dan Pengelolaan Keuangan di Masjid". Simposium Nasional Akuntansi XIV Aceh 2011.

Soemarso S. R. (2004). “Akuntansi Satu Pengantar”. Bukusatu. Edisi lima. Jakata: Salemba Empat.

Sugiyono. (2009). Memahami Penelitian Kualitatif. Bandung : Alfabeta.

Warren, Reeve, dan Fess.(2008) Accounting (Pengantar Akuntansi). Buku Satu. Edisi 2. Jakarta: Salemba Empat.

Wilopo. (2006). “Analisis Faktor-Faktor Yang Berpengaruh Terhadap Kecenderungan Kecurangan Akuntansi: Studi Pada Perusahaan Publik dan Badan Usaha Milik Negara Di Indonesia." Proceeding Simposium Nasional Akuntansi IX Padang. 23-26 Agustus 2006. 